\title{
Comparison of aircraft measurements during GoAmazon2014/5 and
} ACRIDICON-CHUVA

\section{Fan Mei et al.}

Correspondence to: Fan Mei (fan.mei@pnnl.gov)

The copyright of individual parts of the supplement might differ from the CC BY 4.0 License. 
Supplemental material:

\section{Additional observations}

Both aircraft cannot appear at the same location at the same time due to safety concerns.

4 Thus, the approval of a formation (inter-comparison) flight was acquired six months before the 5 campaign through DOE Pacific Northwest Site Office (PNSO) and the Office of Aviation

6 Management (OAM). Essential risk mitigation was also discussed and approved by the Pacific

7 Northwest National Laboratory Aviation Risk Management Committee (PNNL ARMC). During

8 the IOP, both aircraft crew and scientists teams set up a meeting to discuss the potential flight plan.

9 After the flight plan was formed, both pilots briefed the plan to the Brazilian Air Force (BAF) and

10 Airport Traffic Control (ATC). The clear-sky flight would be under Visual Flight Rules (VFR),

11 which means good weather and no cloud, and pilots communicate with each other using an air-to-

12 air frequency. For coordinated flights in cloudy conditions, the G1 and the HALO were both on

13 Instrument Flight Rules (IFR) flight plan.

14 The coordinated flight on October 1, 2014, was initially designed to be a coordinated flight 15 under a cloudy condition, which means the G1 and the HALO flew the same flight leg with at least $16300 \mathrm{~m}$ altitude offset and at least 5 minutes apart. However, the coordinated two flight legs ( 900

$17 \mathrm{~m}$ and $\sim 1200 \mathrm{~m}$ ) are all below the cloud. Thus, the comparison focus on the correlation between 18 two aircraft measurements, not vertical profiling. 


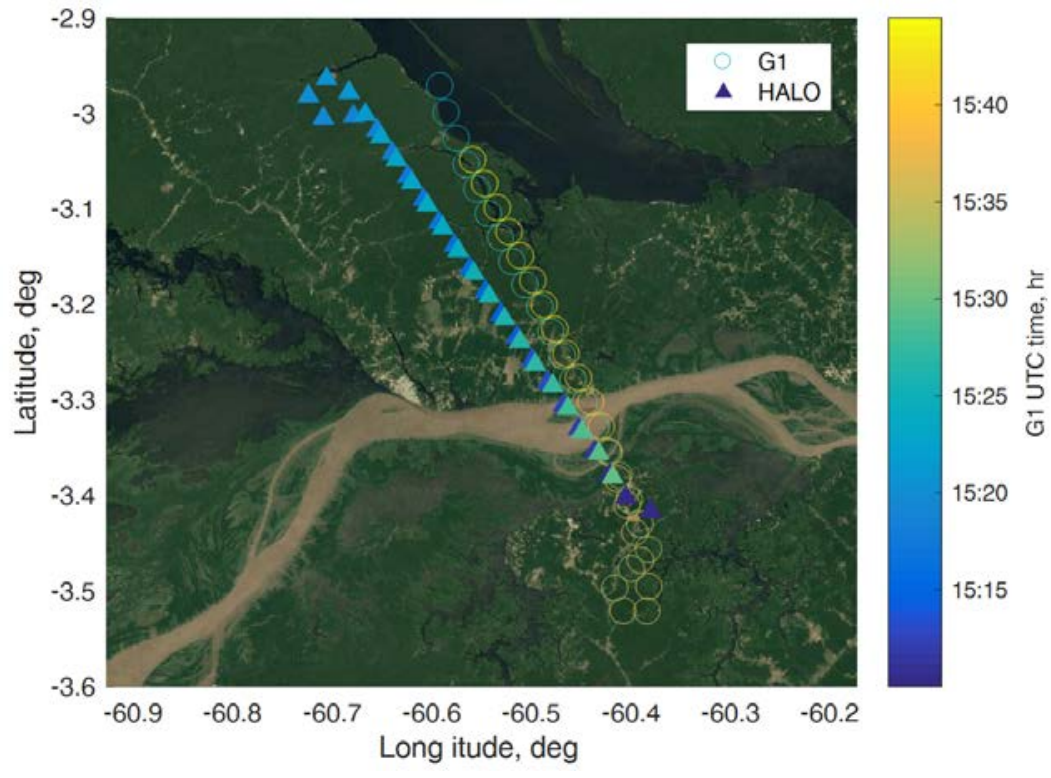

22 Figure S1. Time colored flight track of the G1 (circle) and the HALO (triangle) on October 1, 23 2014, during a cloudless coordinated flight (This figure was created using Mapping Toolbox ${ }^{\mathrm{TM}}$ 24 (C) COPYRIGHT 1997-2019 by The MathWorks, Inc). 

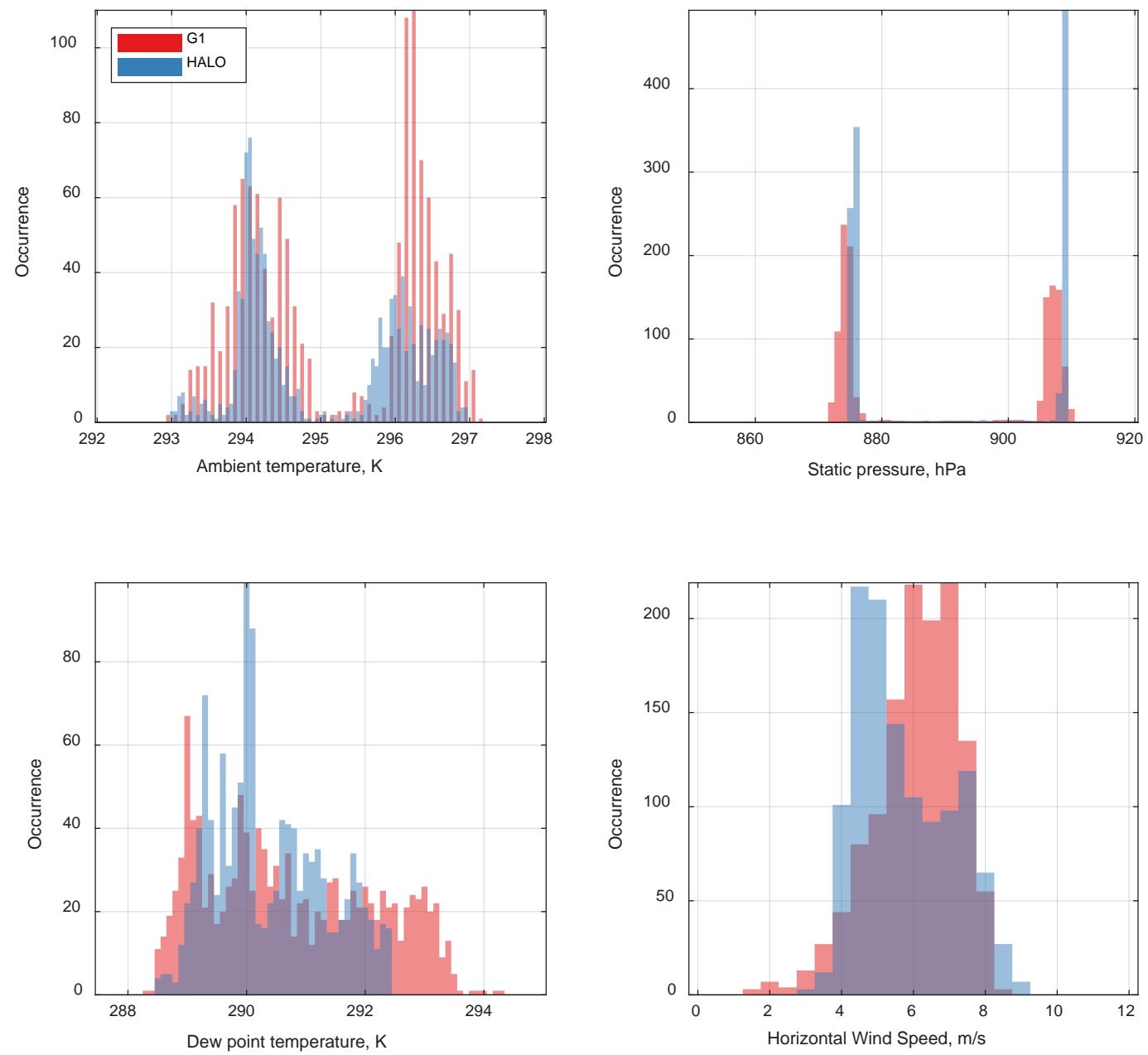

25

Figure S2, Atmospheric parameters observed by the G1 and the HALO on October 1, 2014. 


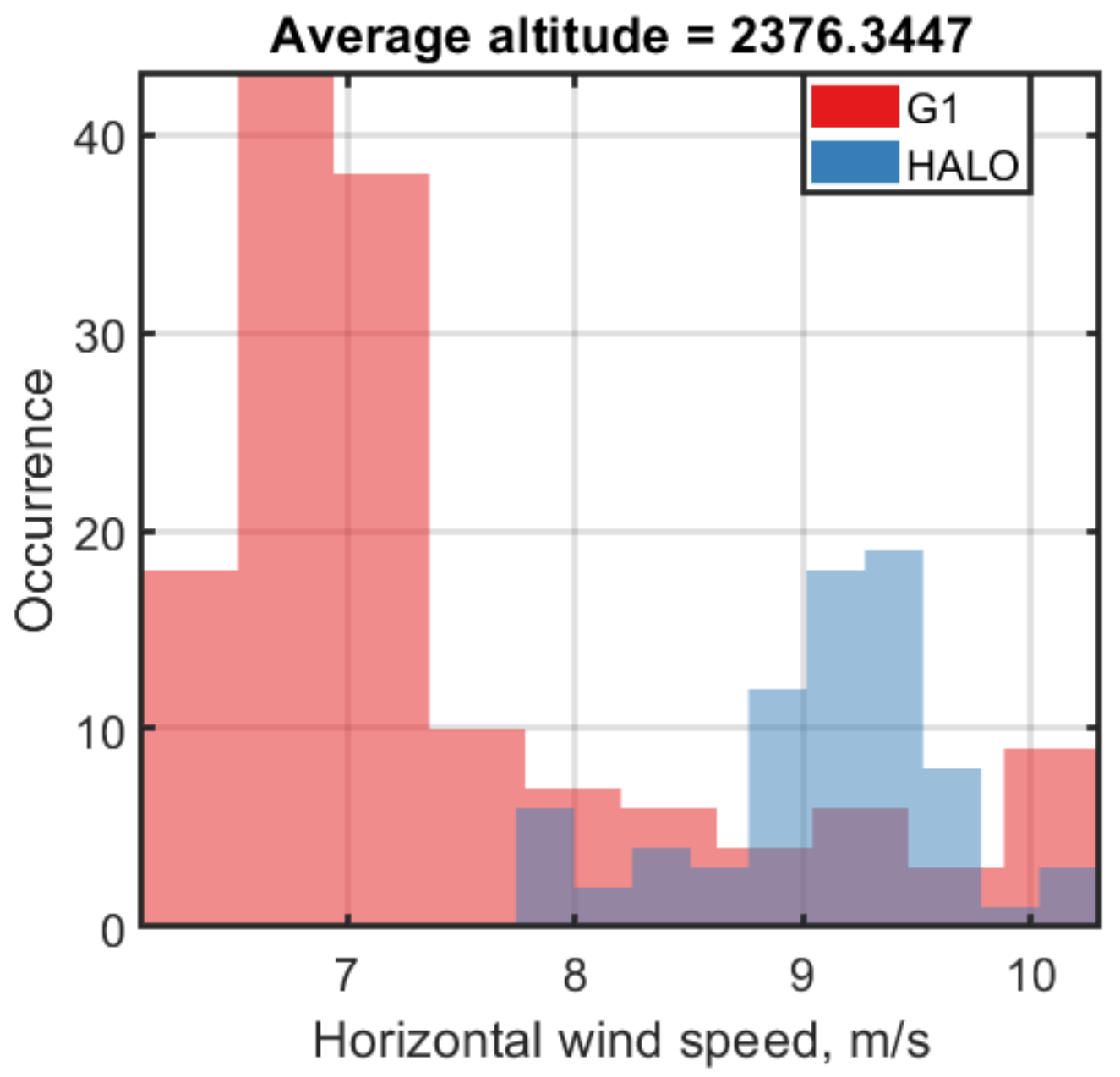

28

Figure S3. Horizontal wind speed between 2000-3000 m altitude on September 21, 2014.

29 


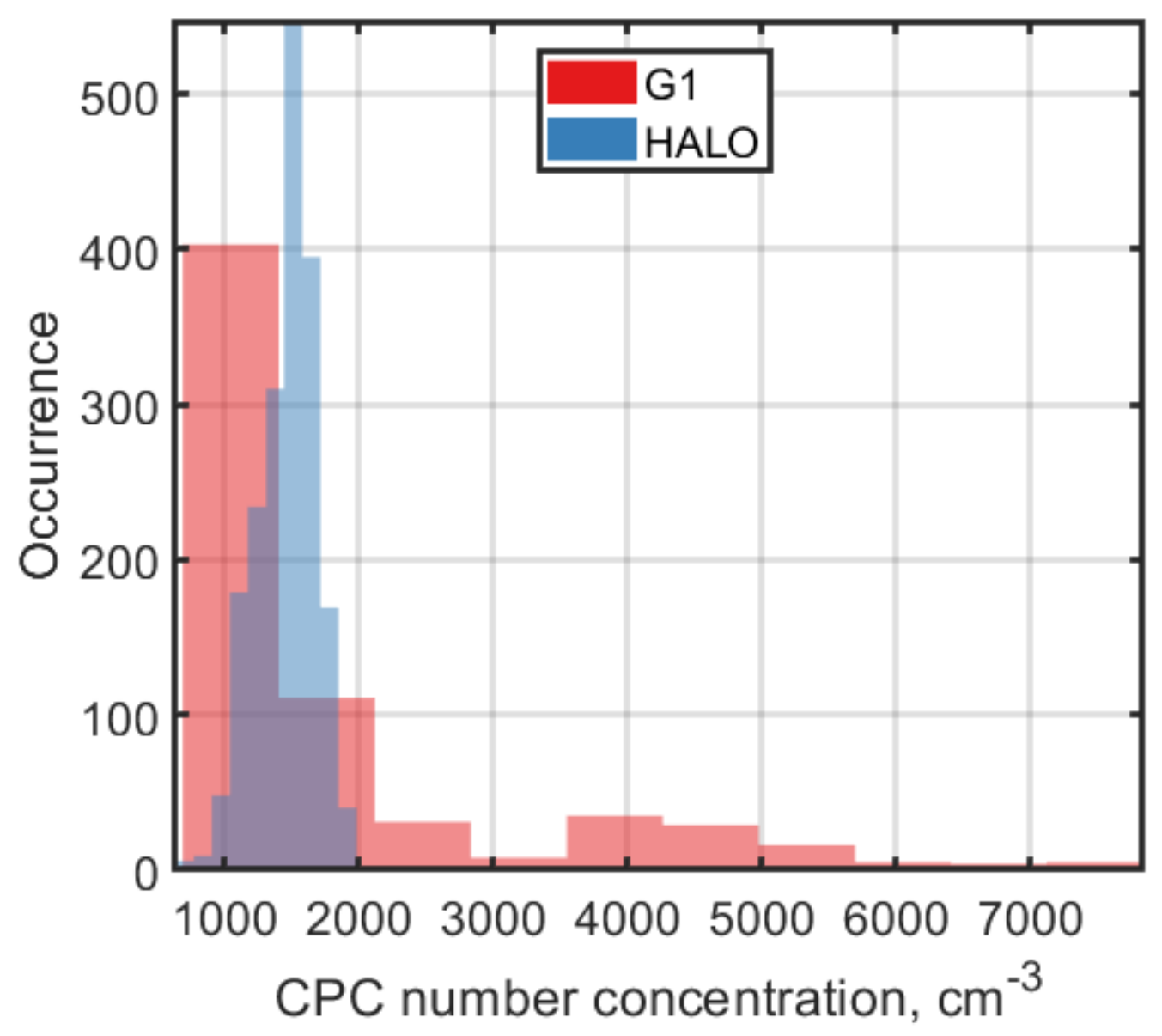

31

(a) 


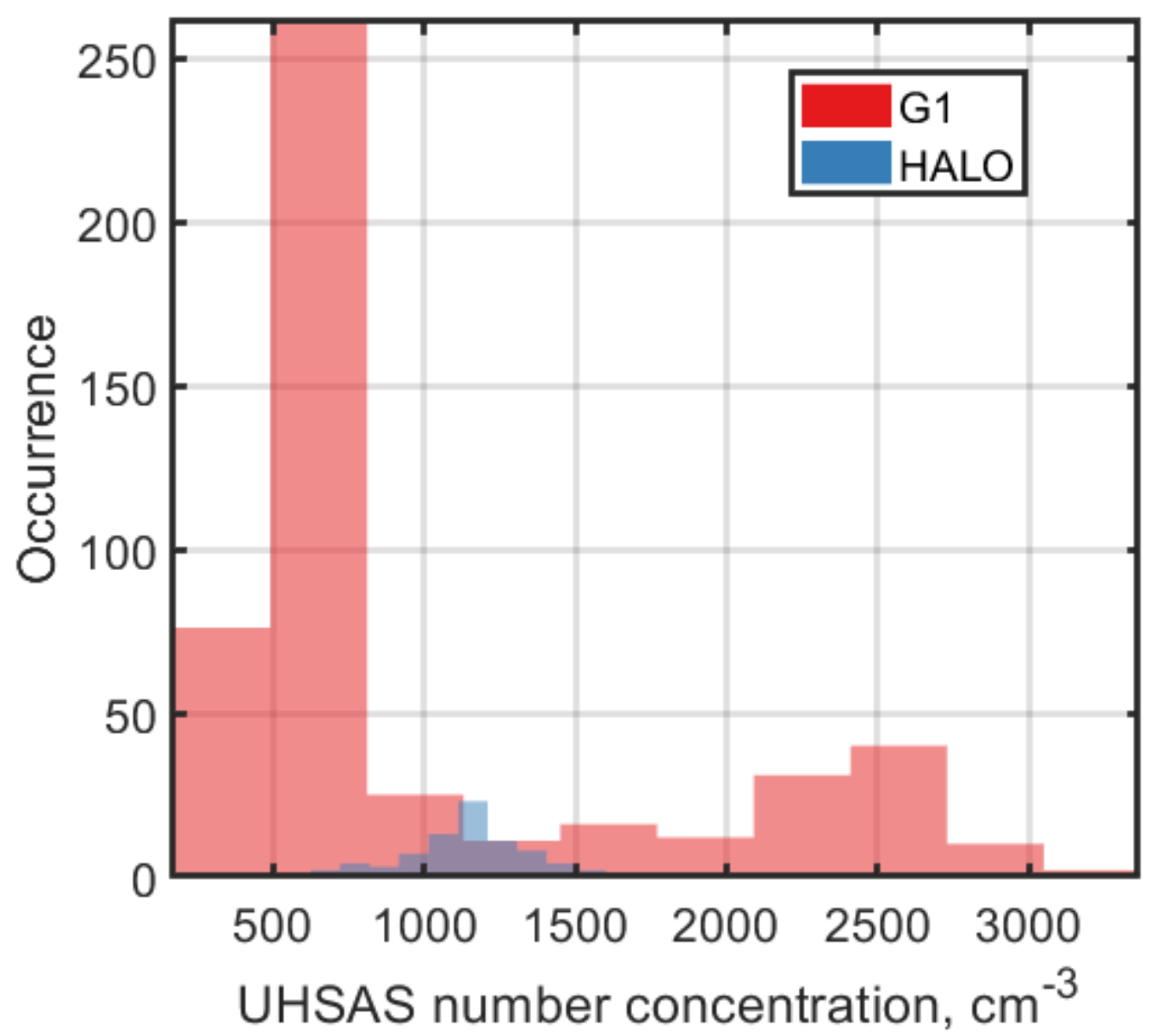

34

(b)

35 Figure S4. The total aerosol particles number concentration between 2000-3000 m altitude on 36 September 21, 2014: (a) CPC measurement; (b) UHSAS measurement. 


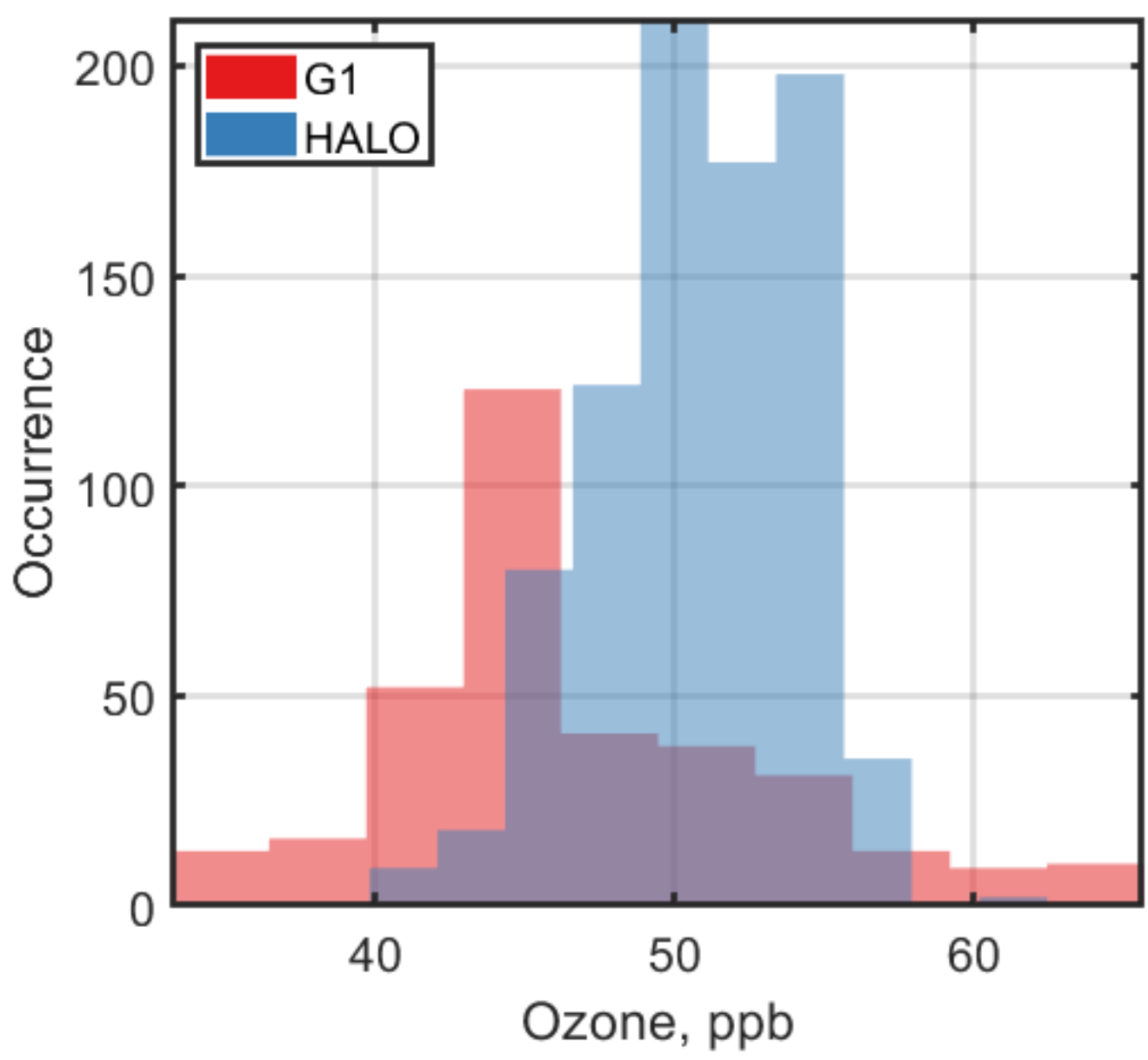

38

(a) 


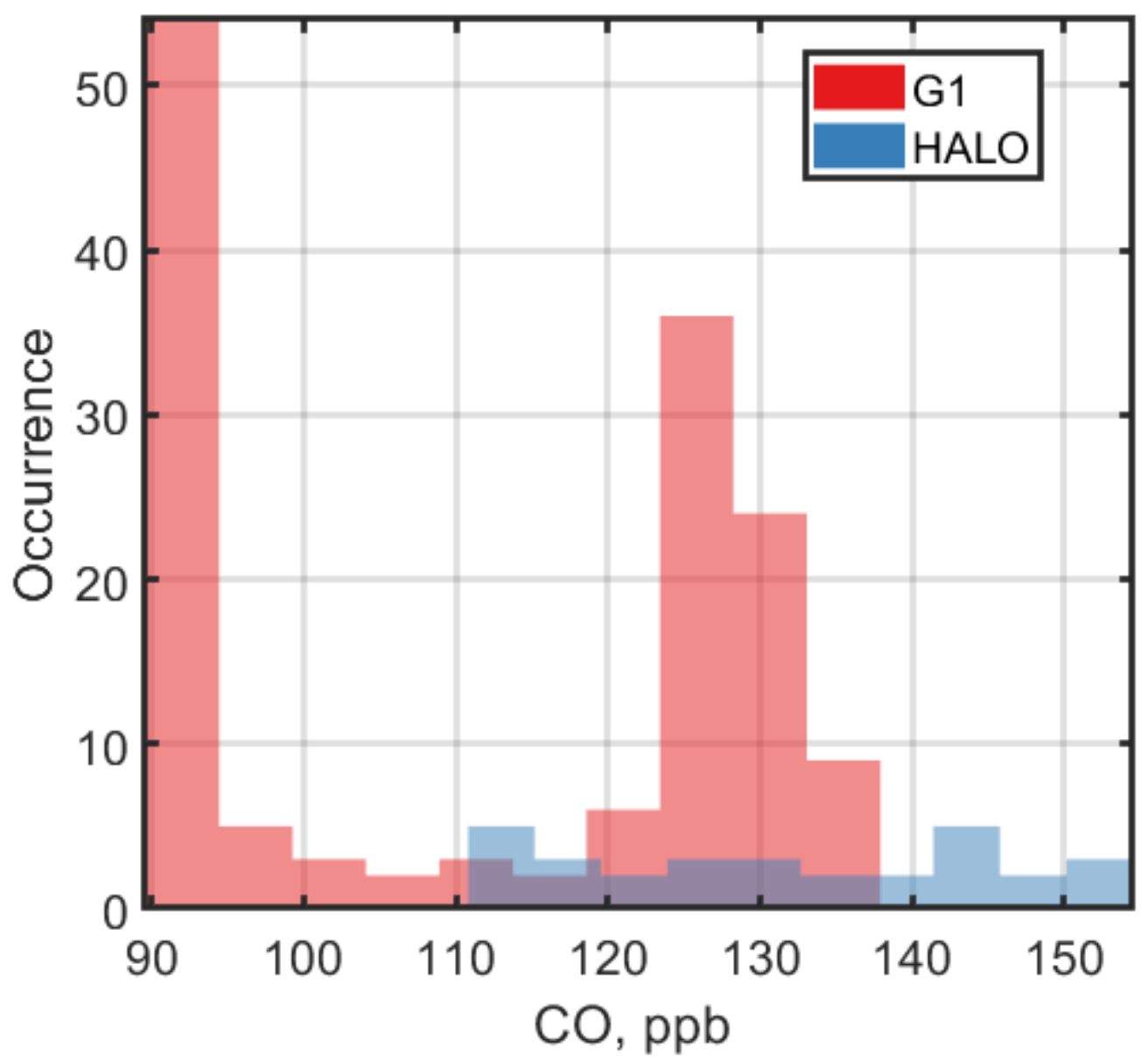

(b)

Figure S5. The trace gas concentration between 2000-3000 m altitude on September 21, 2014:

(a) Ozone measurement; (b) CO measurement.

2. Additional information for AMS

Most of the details for the AMS measurements have been included in the separate AMS papers

46 (Schulz et al., 2018; Shilling et al., 2018). Brief summaries are provided below.

The G1 AMS was operated with a constant pressure inlet (CPI), which was set to a constant 48 pressure during the campaign. The G1 AMS was calibrated once a week during the deployment. 49 One additional calibration was performed after the flight day, and all the calibrations were in 50 agreement with each other. Based on five calibrations, the averaged parameters such as the 
airbeam signal (AB), the ionization efficiency (IE), and the relative ionization efficiency (RIE) were applied to all of the data. A real-time correction was made to account for the variations in the AB changes to improve the instrument sensitivity. Typically, this correction is small $(<20 \%)$ in absolute magnitude. The particle collection efficiency (CE) was determined by comparing AMS data to UHSAS and FIMS data. We also confirmed the $\mathrm{CE}=0.5$ by comparing mass loadings observed at the T3 site to the G1 data.

The HALO AMS was calibrated before, during (twice), and after the campaign for (relative) ionization efficiencies of nitrate, ammonium, and sulfate (Schulz et al., 2018). For organics, the default relative ionization efficiency of 1.4 was assumed. The inlet flow was kept constant by the CPI and was measured before and during the campaign. Collection efficiency of 0.5 was applied, as recommended by Middlebrook et al. (2012) for low nitrate conditions. Further details on the operation of the C-ToF-AMS are given in Schulz et al. (2018).

Figure S6(a) shows vertical profiles of the total mass concentrations measured by the two AMS instruments on September 21. Above $2500 \mathrm{~m}$ altitude, the agreement between the two instruments is excellent (mean difference less than 5\%). Between 2000 and $2500 \mathrm{~m}$, the agreement is within the uncertainty range. Below $2000 \mathrm{~m}$ altitude, however, the aerosol particle mass concentrations measured by the AMS operated on HALO are lower than the concentrations measured by the AMS on the G1. To compare AMS data to UHSAS data, the aerosol mass concentrations of the G1 AMS were converted to the aerosol volume concentration assuming an organic compound density of $1.5 \mathrm{~g} \mathrm{~cm}^{-3}$ (Pöschl et al., 2010). The converted aerosol volume concentration agreed well with the volume concentration calculated based on UHSAS data, especially below $2500 \mathrm{~m}$, as shown in Figure S6(b). The agreement at lower altitudes suggests that the lower concentration measured by the HALO AMS is due to the transmission efficiency issue in the constant pressure inlet used by the HALO AMS. This inlet was a prototype, designed and built at MPIC Mainz, and works by changing the size of the critical orifice that regulates the flow into the aerodynamic lens. The design and transmission characteristics will be described in an upcoming publication (Molleker, S., in prep.). The AMS aboard the G1 used a constant pressure inlet based on the design in Bahreini et al., 2008. Thus, we conclude that data above $2500 \mathrm{~m}$ altitude measured by the AMS aboard HALO in 2014 are valid, while data below 2500 m need to be corrected using correction factors derived from laboratory characterization before further study. 
81 After 2014, the HALO AMS inlet design was improved to address the inlet transmission issues 82 specific to this field campaign.

The second comparison between the two AMS conducted on October 1 is shown in Figures

84 S6 and S7. The findings are basically in agreement with those of September 21, although the 85 underestimation of aerosol mass concentration due to the inlet in the HALO AMS appears here to 86 be restricted to altitudes lower than $1500 \mathrm{~m}$.

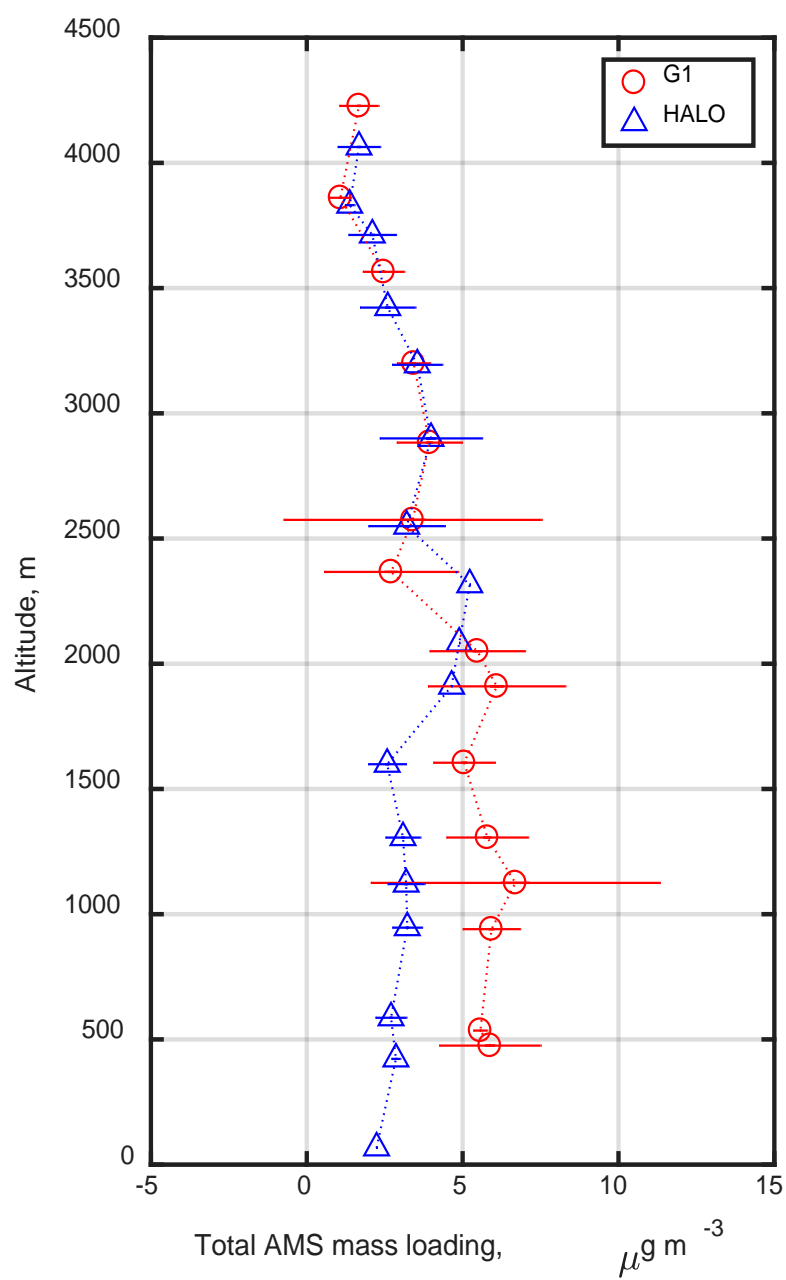

(a)

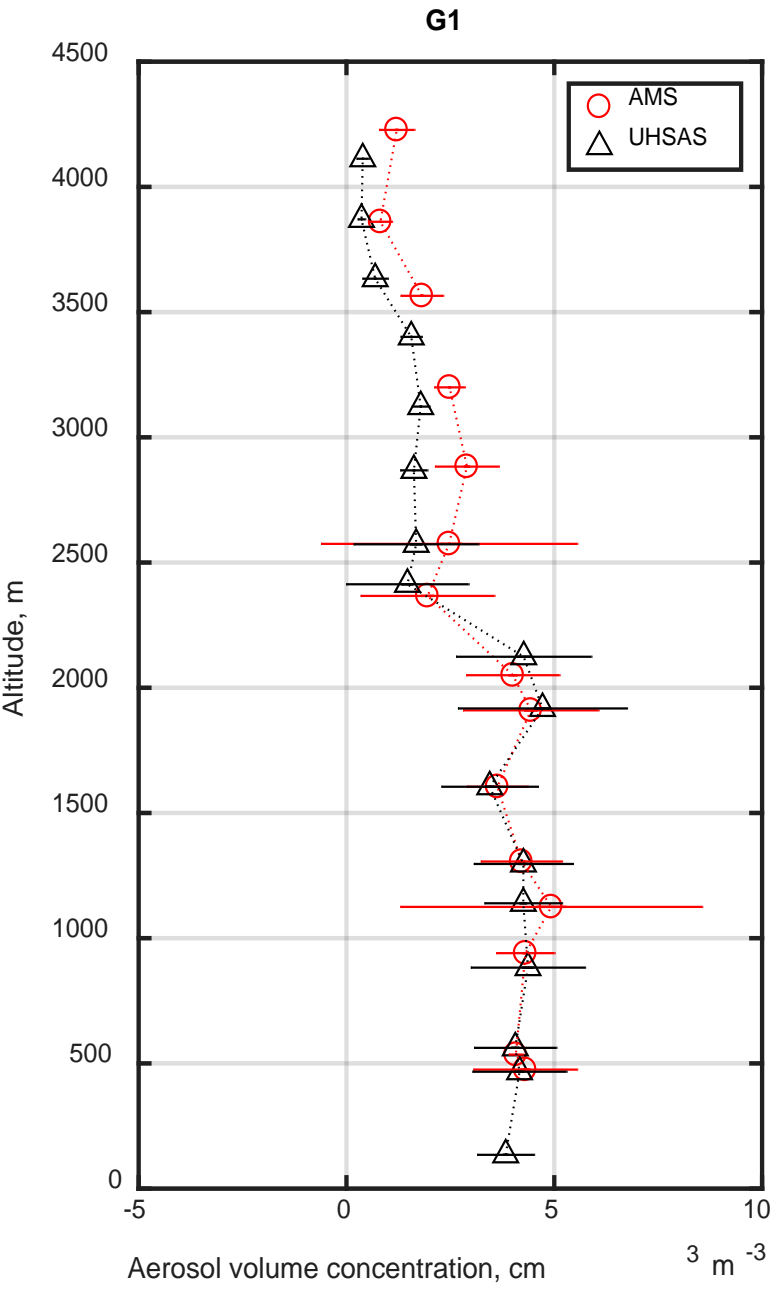

(b) 
92

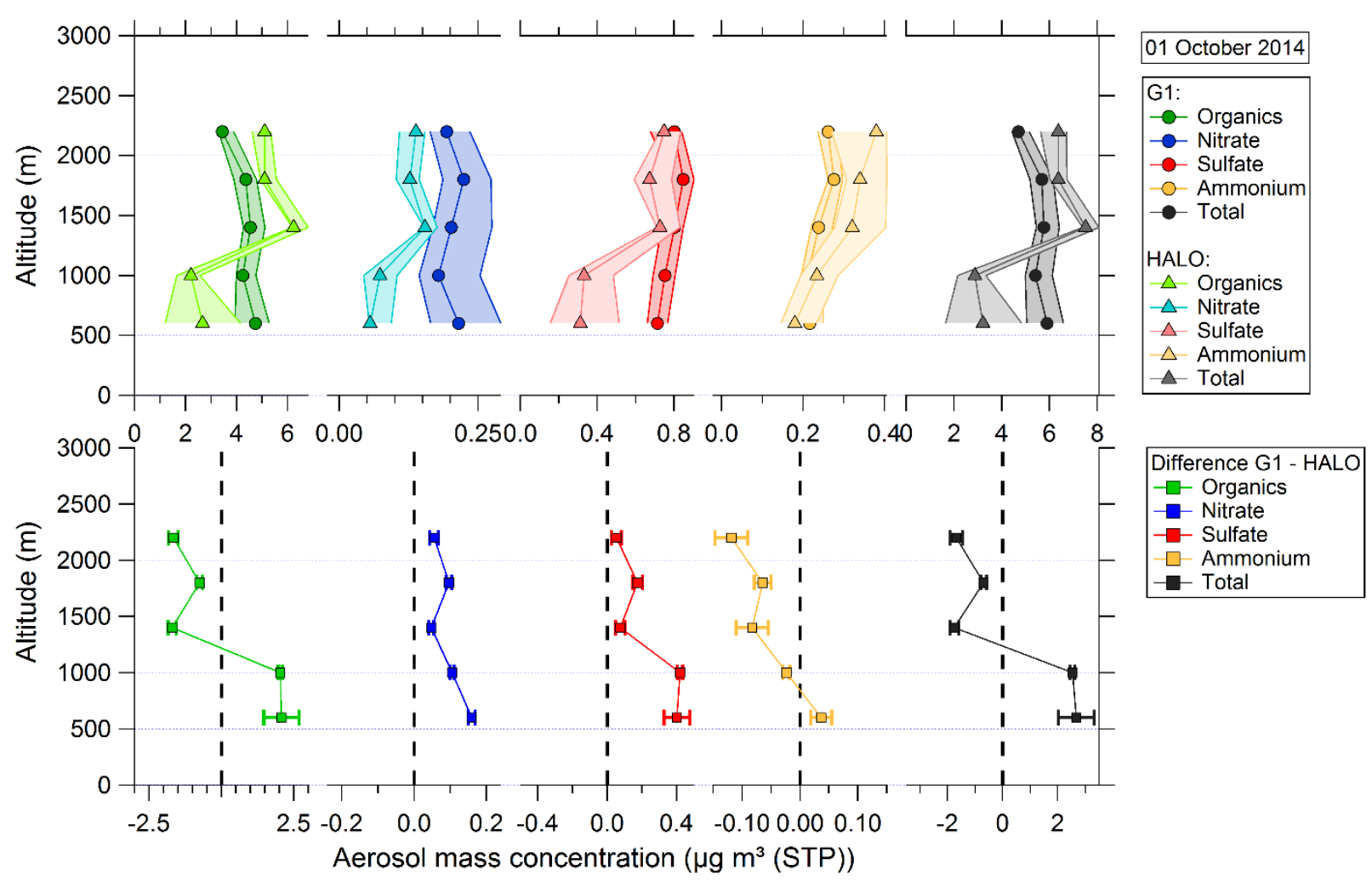

94 Figure S7. The vertical profiling of the aerosol mass concentration observed by the G1 and 


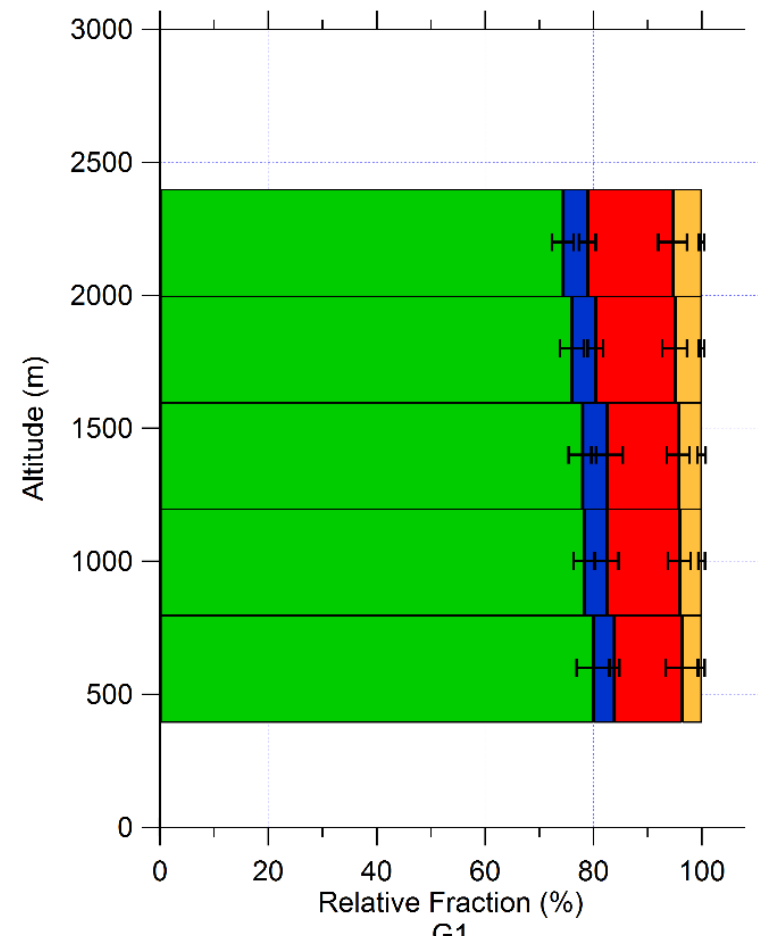

G1

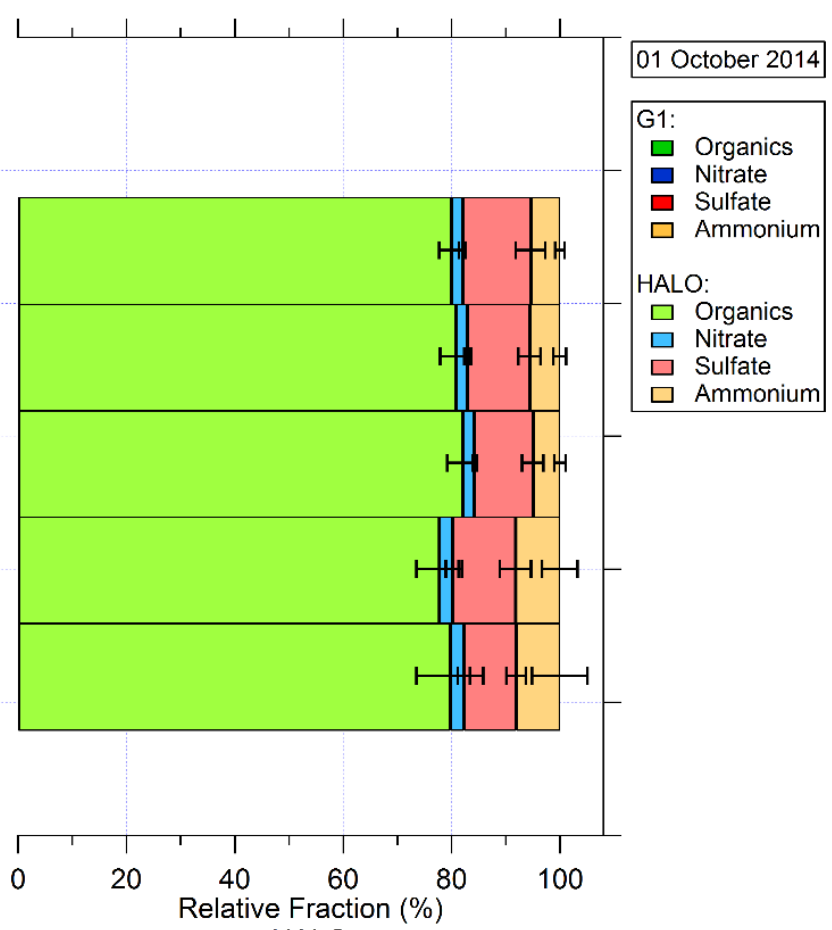

HALO

Figure S8. The vertical profiling of the relative fractions for the chemical species observed by the G1 and HALO during October 1.

\section{CCN closure}

To further examine the relative importance of mixing state and chemical composition, the CCN concentrations were calculated from aerosol particle size distribution, and chemical composition measured onboard the G1. The calculation was based on $\kappa$-Köhler parameterization, (Kohler, 1936; Petters and Kreidenweis, 2007, 2008, 2013) and the detail of the approach was described by Mei et al. (2013b). For the flight on September 9, 2017, the CCN number concentration calculated from the G1 UHSAS size distribution and chemical composition exhibits underestimation at a supersaturation of $0.5 \%$ (Fig, S9(a)) and when the altitude is below $1000 \mathrm{~m}$ (Fig S9(b)). This underestimation suggests that the UHSAS size range (90-500 $\mathrm{nm}$ ) did not fully cover the aerosols with the critical activation diameter $\left(D_{\mathrm{p}, 50}\right)$ at high supersaturation. Thus, the FIMS measurements onboard the G1 was the more appropriate size distribution for both the CCN closure study. The CCN concentration calculated using the size distribution from FIMS agrees 
114 well with the measurement (Fig. S10). The scattering of the comparison data in Figure 15 is likely

115 due to the chemical composition and mixing state effect on aerosol hygroscopicity.

116

117

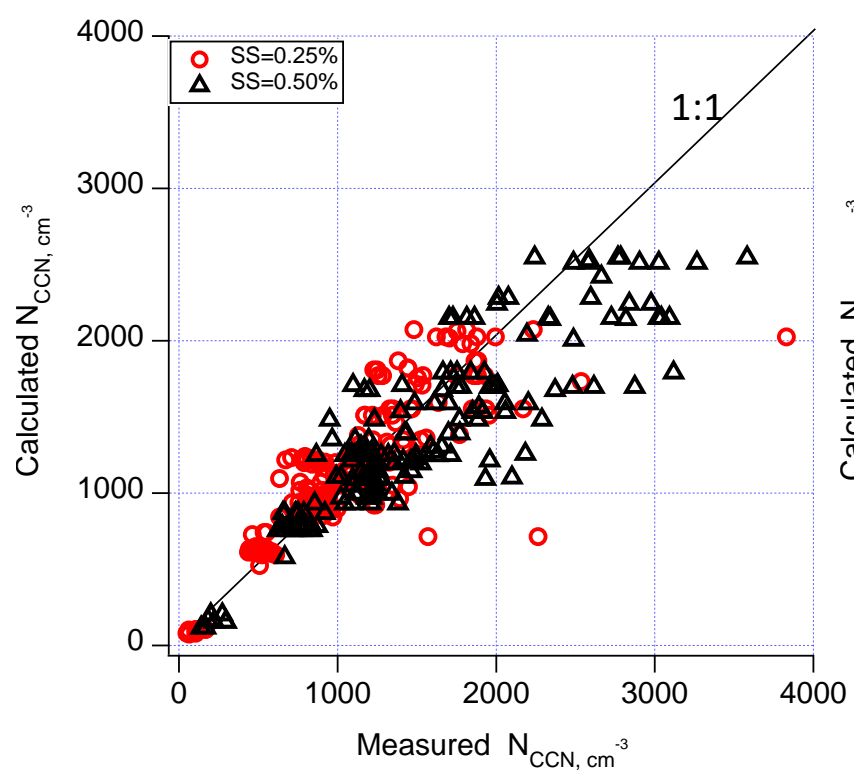

(a)

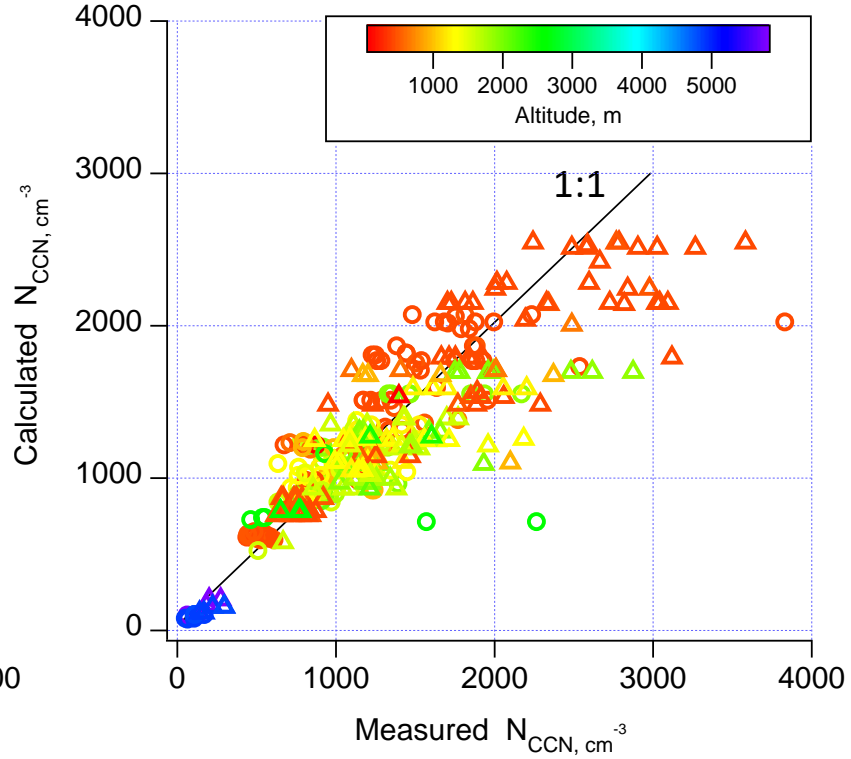

(b)

120 Figure S9. Comparison of calculated CCN with measured CCN using the averaged 1 min 121 measurements from the G1: (a) colored by different supersaturations. (b) colored by different 122 altitudes. (Note that both plots used the calculated CCN number concentration from UHSAS size 123 distribution.) 


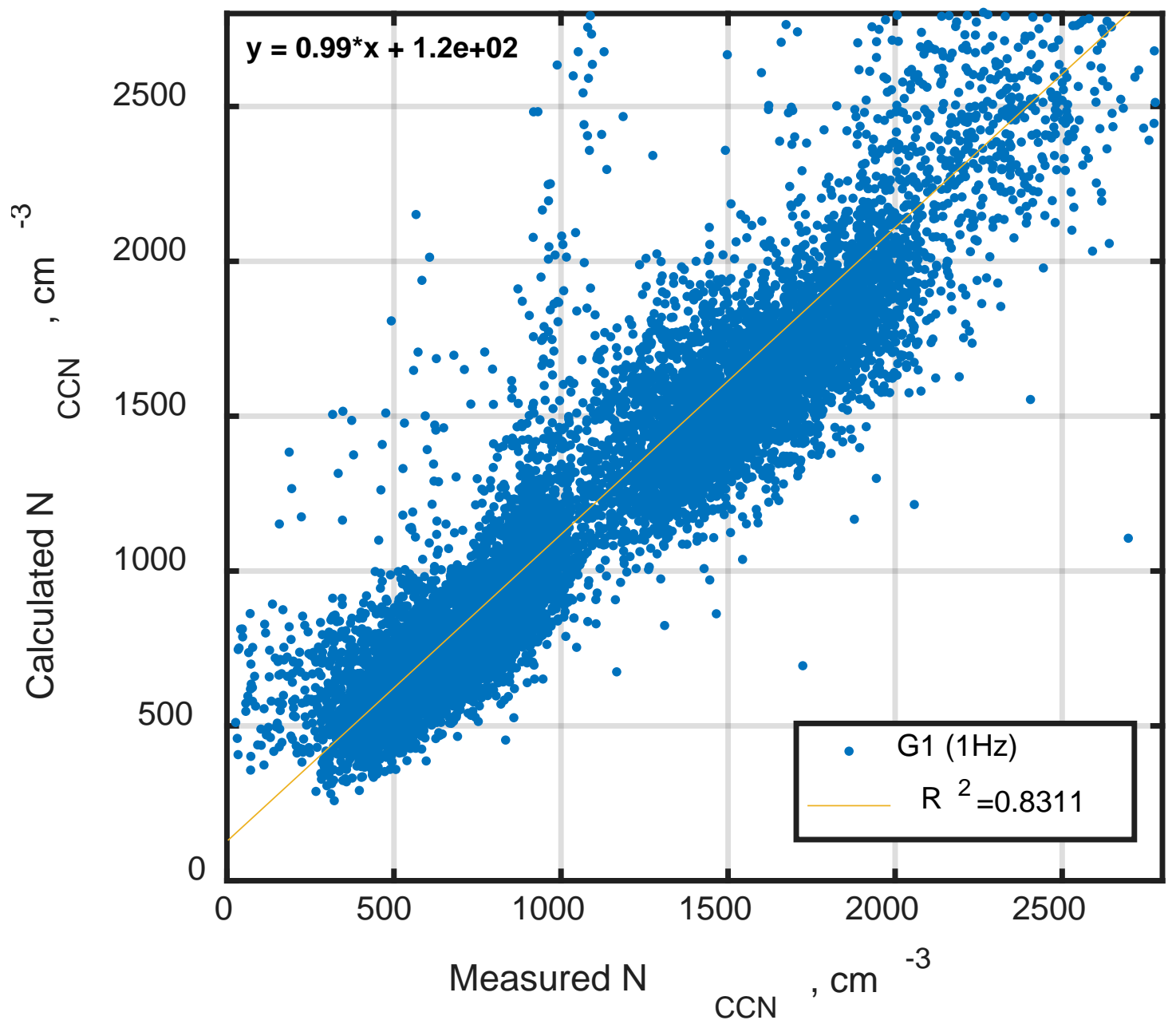

124

Figure S10. The scatter plot of the calculated CCN number concentration using FIMS size distribution compared with the measured CCN number concentration 


\section{Cloud probe observations}

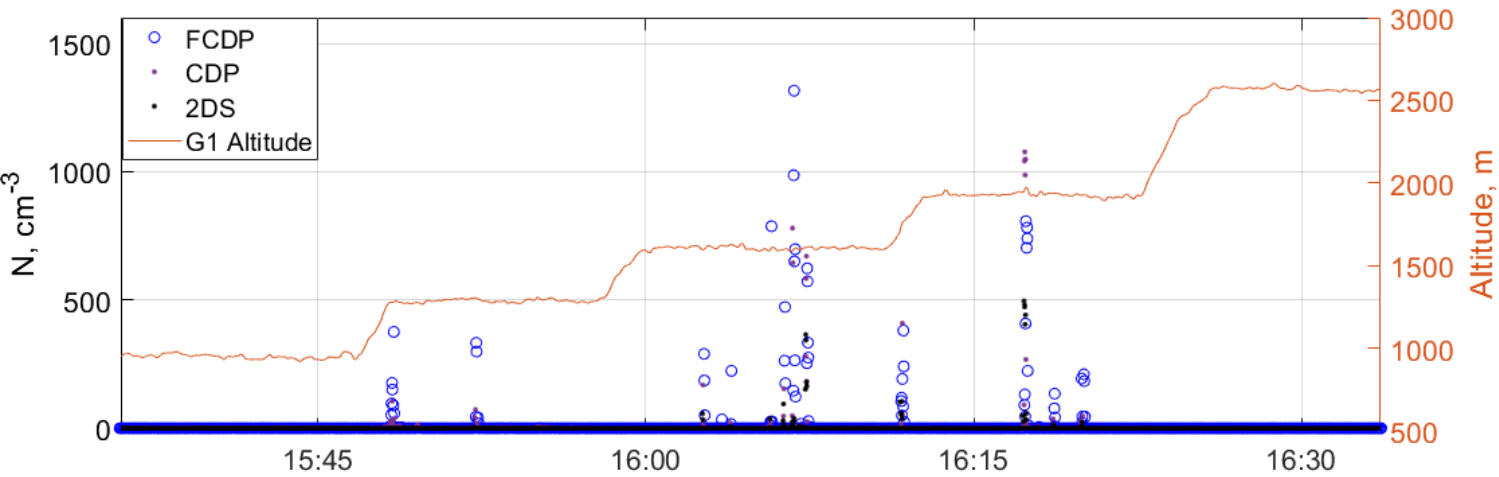

137 Figure S11. The cloud droplet number concentration from the G1 aircraft on September 21.
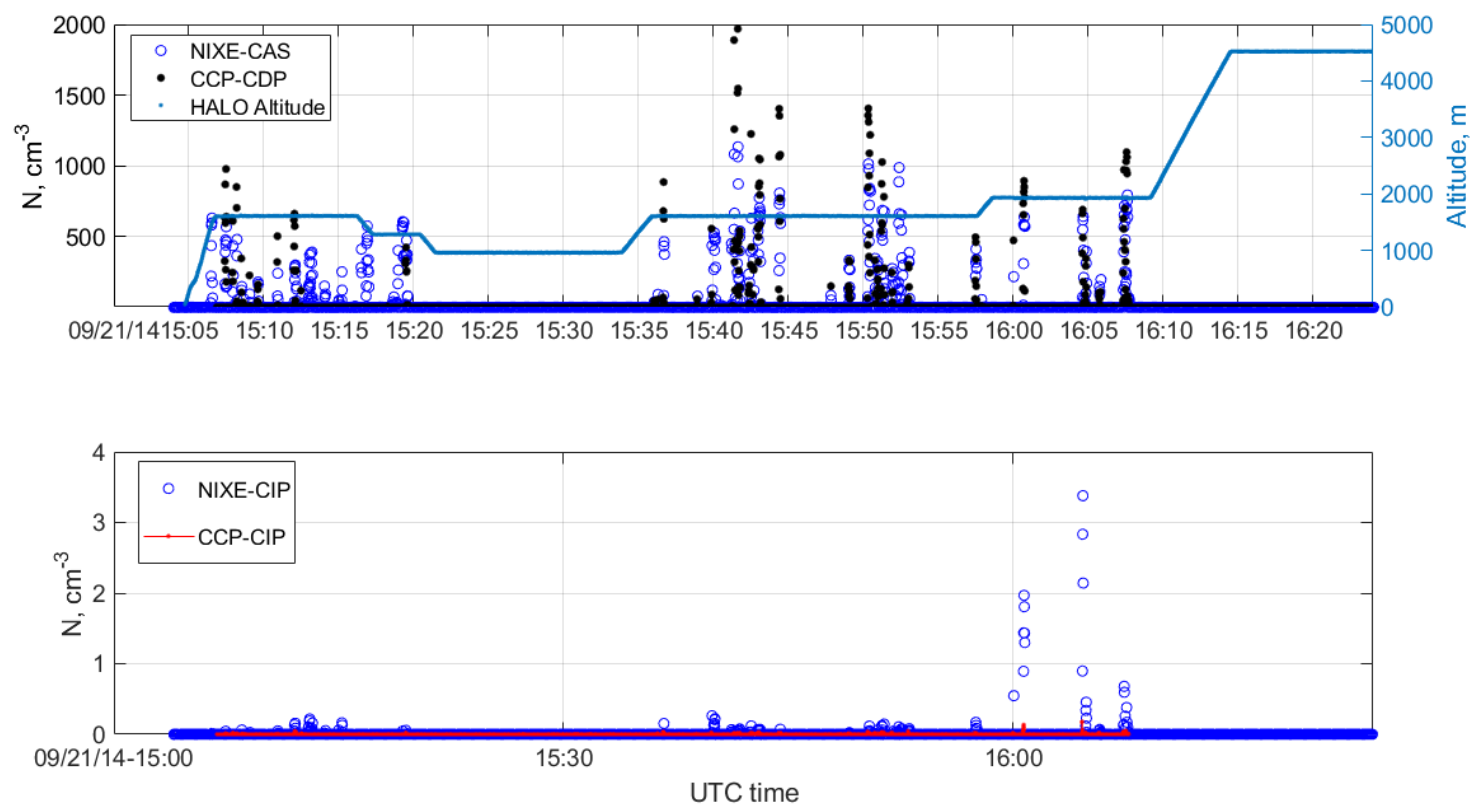

139

Figure S12. The cloud droplet number concentration from HALO on September 21. 


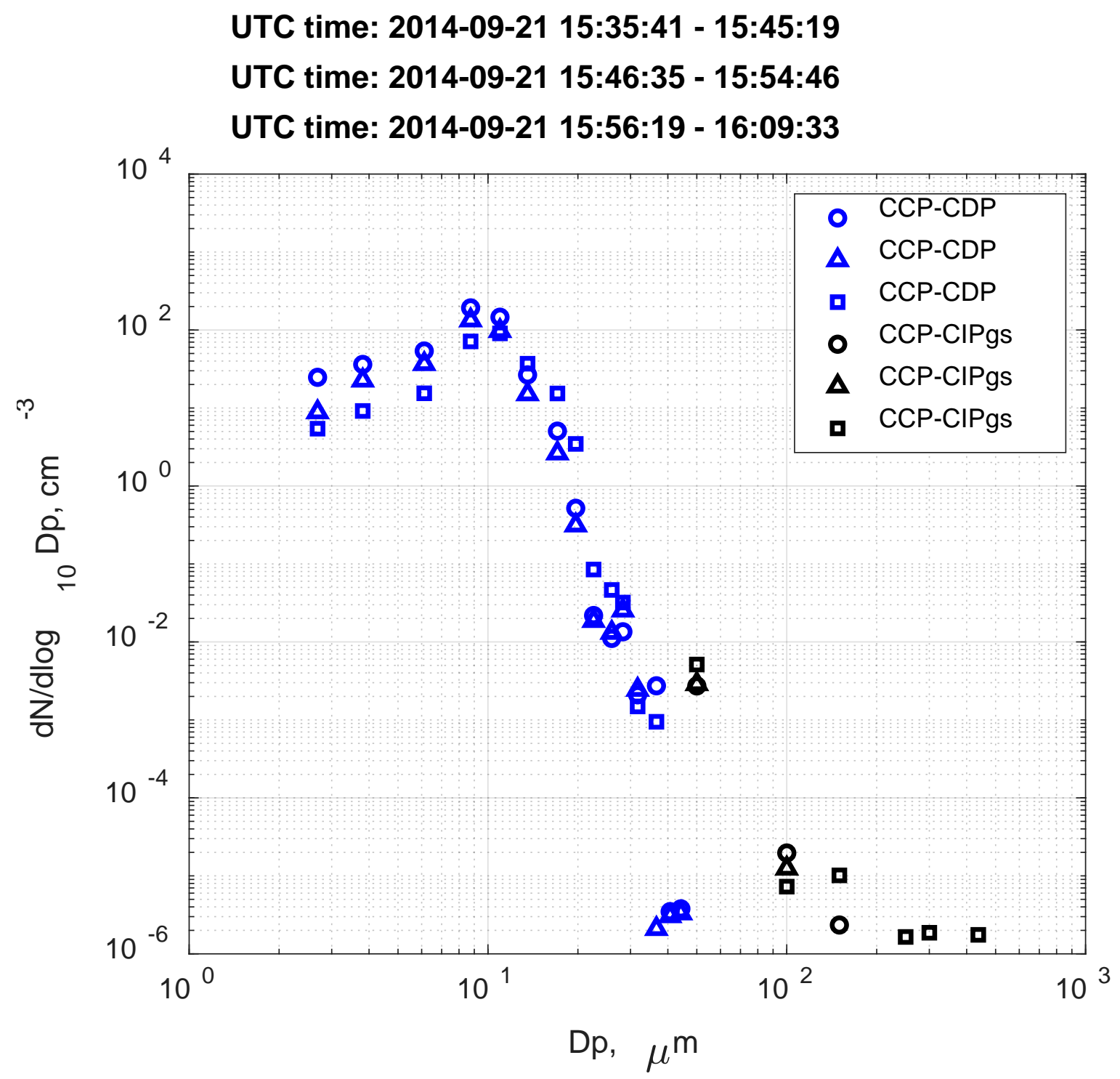

141

(a) 


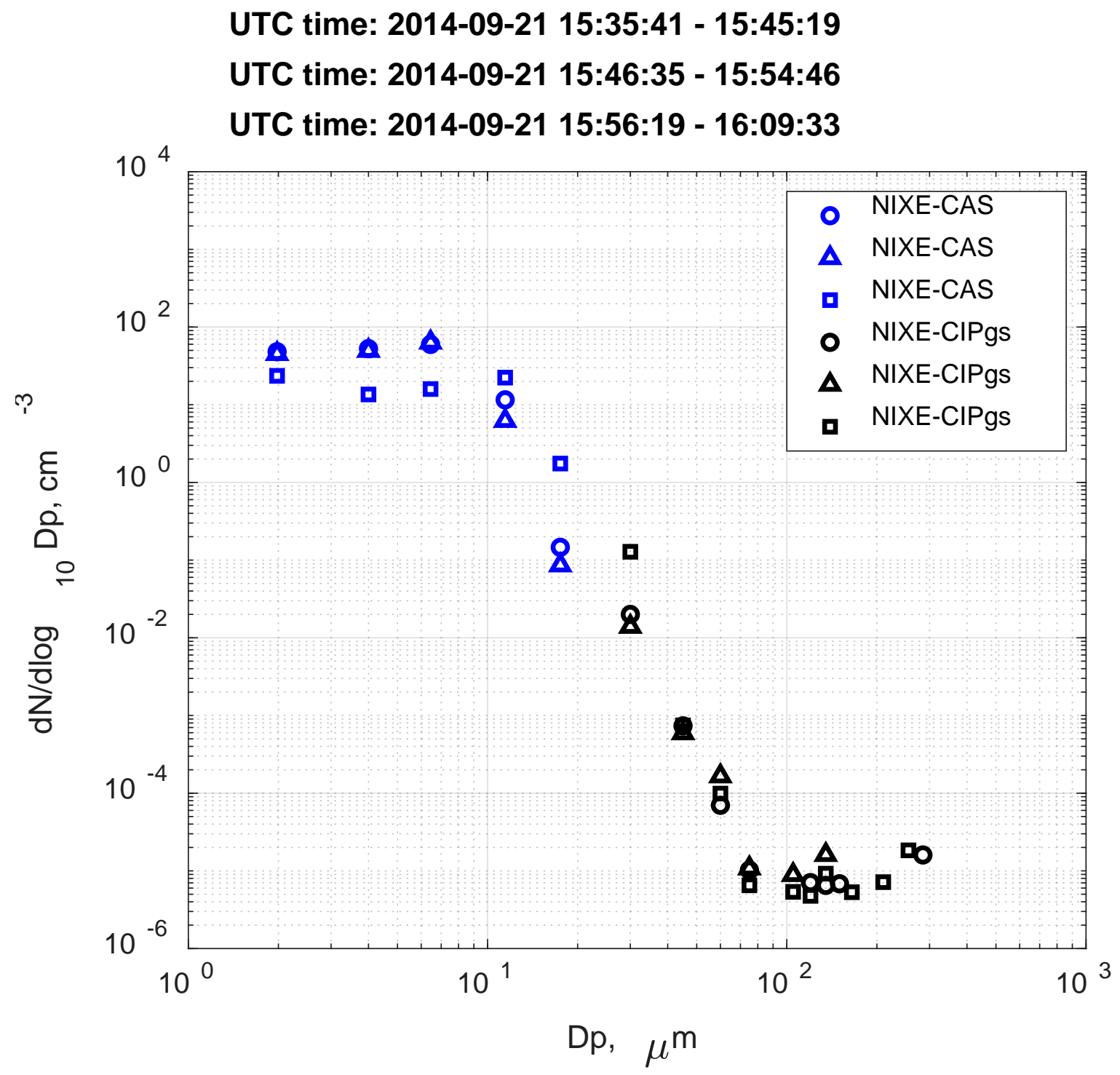

(b) 


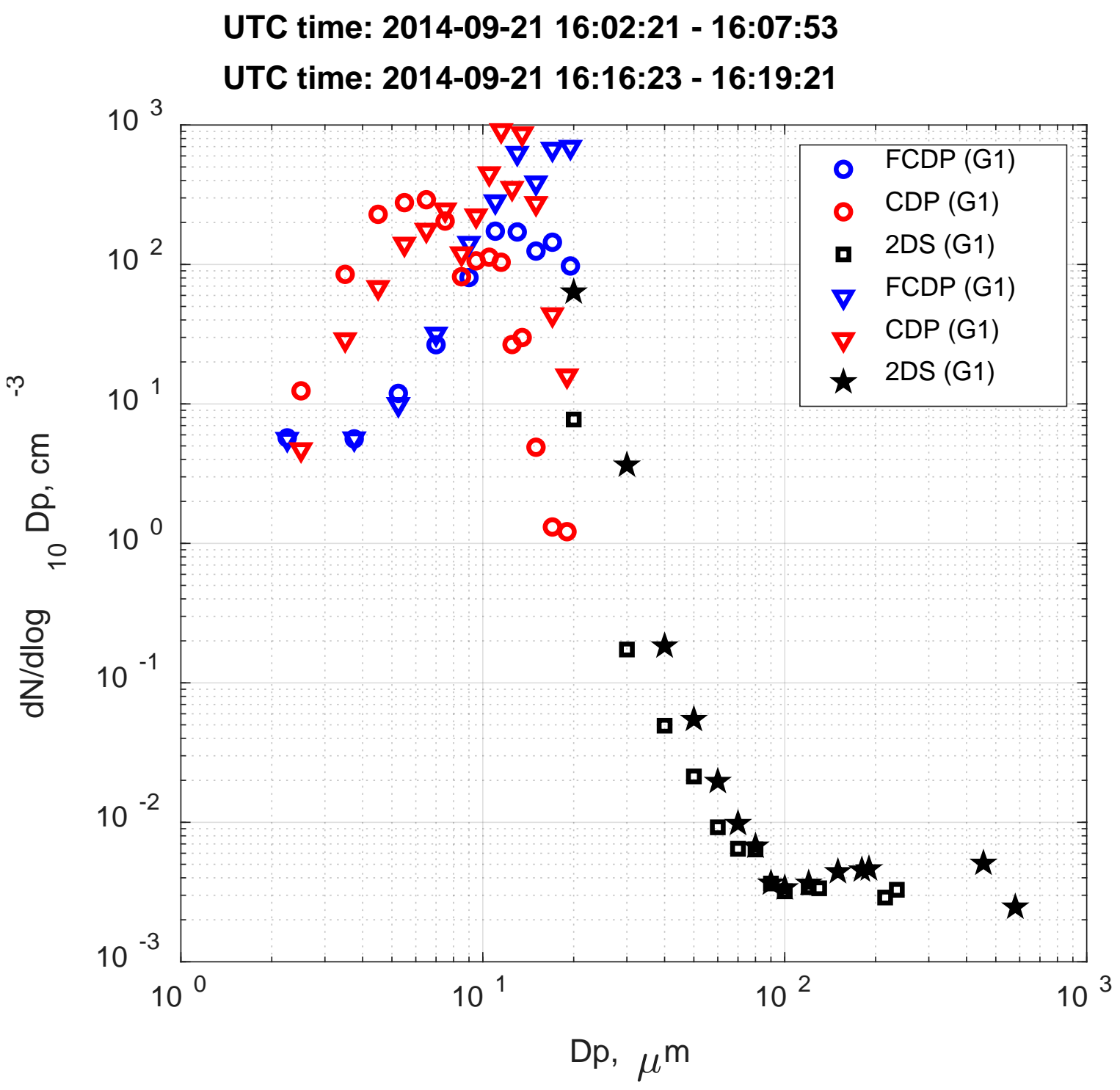

146

(c)

147 Figure S13. The averaged cloud droplet size distributions from HALO on September 21, (a) CCP probes; (b) NIXE-CAPS probes; (c) Cloud probes on board the G1. 


\section{Radiation measurements}

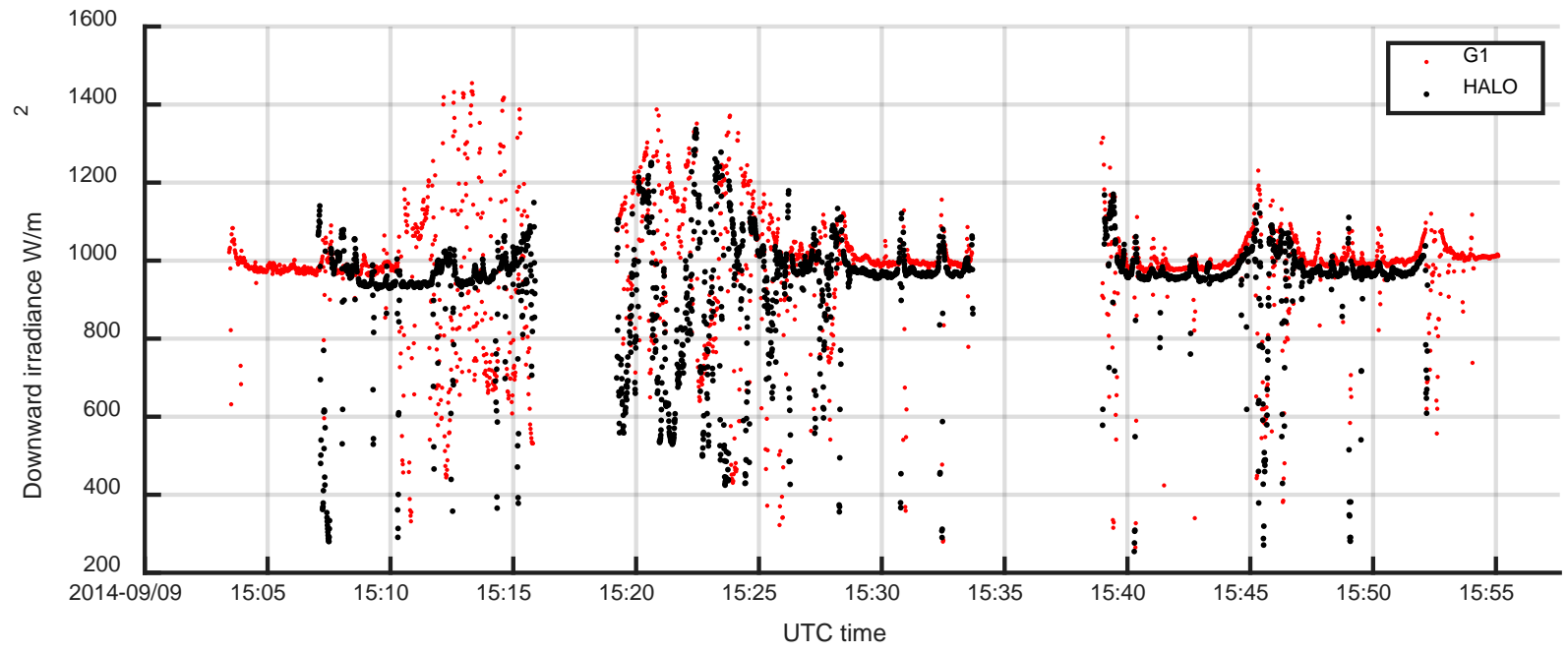

156

Figure S14. Time series comparison of the G1 (SPN-1) and HALO (SMART-Albedometer) radiation measurements on September 9.

Table S1. Calibration and maintenance for the instruments deployed on G1

\begin{tabular}{|l|l|l|}
\hline Measurement Variables & $\begin{array}{l}\text { Instruments deployed on the G1 } \\
\text { (Martin et al., 2016; Schmid et } \\
\text { al., 2014) }\end{array}$ & Calibration/Maintenance \\
\hline Static Pressure & Rosemount (1201F1), 0-1400 hPa & $\begin{array}{l}\text { Calibrated before/after each field } \\
\text { campaign }\end{array}$ \\
\hline Static air temperature & $\begin{array}{l}\text { Rosemount E102AL/510BF } \\
-50 \text { to }+50^{\circ} \mathrm{C}\end{array}$ & $\begin{array}{l}\text { Calibrated before/after each field } \\
\text { campaign }\end{array}$ \\
\hline Dewpoint temperature & $\begin{array}{l}\text { Chilled mirror hygrometer 1011B } \\
-40 \text { to }+50^{\circ} \mathrm{C}\end{array}$ & $\begin{array}{l}\text { Calibrated before/after each field } \\
\text { campaign }\end{array}$ \\
\hline 3-D wind & $\begin{array}{l}\text { Aircraft Integrated Meteorological } \\
\text { Measurement System 20 (AIMMS- } \\
20)\end{array}$ & $\begin{array}{l}\text { Calibrated with Special flight pattern } \\
\text { before each field campaign. Inter- } \\
\text { comparison with other GPS/INS } \\
\text { during deployment. }\end{array}$ \\
\hline Particle number concentration & CPC, cut off size $\left(D_{\mathrm{p}}\right)=10 \mathrm{~nm}$ & $\begin{array}{l}\text { Calibrated before/after each field } \\
\text { campaign. Weekly calibration of } \\
\text { sample and sheath flow rates and } \\
\text { inter-comparisons with similar } \\
\text { counters during deployment. }\end{array}$ \\
\hline Size distribution* & $\begin{array}{l}\text { Calibrated before/after each field } \\
\text { campaign. Weekly check of sizing } \\
\text { with PSL }\end{array}$ \\
\hline FIMS & $\begin{array}{l}\text { Calibrated before/after each field } \\
\text { campaign. Weekly calibration of } \\
\text { sample and sheath flow rates and } \\
\text { checks with one size PSL }\end{array}$ \\
\hline
\end{tabular}




\begin{tabular}{|l|l|l|}
\hline $\begin{array}{l}\text { Non-Refractory particle chemical } \\
\text { composition }\end{array}$ & $\begin{array}{l}\text { HR-ToF-AMS: Organics, Sulfate, } \\
\text { Nitrate, Ammonium, Chloride, 60- } \\
1000 \mathrm{~nm}\end{array}$ & Weekly calibrations. \\
\hline CCN concentration & CCN-200, SS $0.25,0.5 \%$ & $\begin{array}{l}\text { Calibrated before/after each field } \\
\text { campaign. Biweekly calibration with } \\
\text { ammonium sulfate particles. }\end{array}$ \\
\hline Gas phase concentration & $\begin{array}{l}\mathrm{N} 2 \mathrm{O} / \mathrm{CO} \text { and Ozone Analyzer, CO, } \\
\text { O3 concentration, precision 2 ppb }\end{array}$ & $\begin{array}{l}\text { Calibrated before/after each field } \\
\text { campaign with calibration gas } \\
\text { mixture. }\end{array}$ \\
\hline CDP & $2-50 \mu \mathrm{m}, \Delta D_{\mathrm{p}}=1-2 \mu \mathrm{m}$ & $\begin{array}{l}\text { Calibrated before/after each field } \\
\text { campaign by the vendor. Weekly } \\
\text { check of sizing with glass beads of } \\
\text { several sizes }\end{array}$ \\
\hline FCDP & $2-50 \mu \mathrm{m}, \Delta D_{\mathrm{p}}=1-2 \mu \mathrm{m}$ & $\begin{array}{l}\text { Calibrated before/after each field } \\
\text { campaign by the vendor. Weekly } \\
\text { check of sizing with glass beads of } \\
\text { several sizes }\end{array}$ \\
\hline 2DS & $\begin{array}{l}\text { Calibrated before/after each field } \\
\text { campaign by the vendor. }\end{array}$ \\
\hline Radiation & $10-1000 \mu \mathrm{m}$ & $\begin{array}{l}\text { Calibrated before/after each field } \\
\text { campaign }\end{array}$ \\
\hline
\end{tabular}

161

162 Table S2. Calibration and maintenance for the instruments deployed on HALO

\begin{tabular}{|l|l|l|}
\hline Measurement Variables & $\begin{array}{l}\text { Instruments deployed on HALO } \\
\text { (Wendisch et al., 2016) }\end{array}$ & Calibration/Maintenance \\
\hline Static Pressure & $\begin{array}{l}\text { Instrumented nose boom tray (DLR } \\
\text { development), 0-1400 hPa }\end{array}$ & $\begin{array}{l}\text { Calibrated before/after each field } \\
\text { campaign }\end{array}$ \\
\hline Static air temperature & $\begin{array}{l}\text { Total Air Temperature (TAT) inlet } \\
\text { an open wire resistance temperature } \\
\text { sensor (PT100), } \\
-70 \text { to +50 }{ }^{\circ} \text { C }\end{array}$ & $\begin{array}{l}\text { Calibrated before/after each field } \\
\text { campaign }\end{array}$ \\
\hline Dewpoint temperature & $\begin{array}{l}\text { Derived from the water-vapor mixing } \\
\text { ratio, which is measured by a tunable } \\
\text { diode laser (TDL) system (DLR } \\
\text { development), 5-40000 ppmv }\end{array}$ & $\begin{array}{l}\text { Calibrated before/after each field } \\
\text { campaign }\end{array}$ \\
\hline 3-D wind & $\begin{array}{l}\text { Instrumented nose boom tray (DLR } \\
\text { development) with an air data probe } \\
\text { (Goodrich/Rosemount) 858AJ and } \\
\text { high-precision Inertial Reference } \\
\text { System (IGI IMU-IIe) }\end{array}$ & $\begin{array}{l}\text { Calibrated before/after each field } \\
\text { campaign }\end{array}$ \\
\hline Particle number concentration & $\begin{array}{l}\text { CPC, cut off size }\left(D_{\mathrm{p}}\right)=10 \mathrm{~nm} \\
\text { Size distribution* }\end{array}$ & $\begin{array}{l}\text { Calibrated before/after each field } \\
\text { campaign. Weekly inter-comparisons } \\
\text { with similar counters during } \\
\text { deployment. }\end{array}$ \\
\hline $\begin{array}{l}\text { Non-Refractory particle chemical } \\
\text { composition }\end{array}$ & $\begin{array}{l}\text { Calibrated before/after each field } \\
\text { campaign. Weekly check of sizing } \\
\text { with PSL }\end{array}$ \\
\hline
\end{tabular}




\begin{tabular}{|l|l|l|}
\hline CCN concentration & CCN-200, SS= 0.13-0.53\% & $\begin{array}{l}\text { Calibrated before/after each field } \\
\text { campaign. Weekly calibration with } \\
\text { ammonium sulfate particles. }\end{array}$ \\
\hline Gas phase concentration & $\begin{array}{l}\text { N2O/CO and Ozone Analyzer, CO, } \\
\text { O3 concentration, precision 2 ppb }\end{array}$ & $\begin{array}{l}\text { Calibrated before/after each field } \\
\text { campaign with calibration gas } \\
\text { mixture. }\end{array}$ \\
\hline Cloud properties* & CCP-CDP, 2.5-46 mm, $\Delta D_{\mathrm{p}}=1-2 \mu \mathrm{m}$ & $\begin{array}{l}\text { Calibrated before/after each field } \\
\text { campaign. Weekly check of sizing } \\
\text { with glass beads of several sizes }\end{array}$ \\
\hline & NIXE-CAS: $0.61-52.5 \mu \mathrm{m}$ & $\begin{array}{l}\text { Calibrated before/after each field } \\
\text { campaign. Weekly check of sizing } \\
\text { with glass beads of several sizes }\end{array}$ \\
\hline & NIXE-CIPgs, 15-960 $\mu \mathrm{m}$ & $\begin{array}{l}\text { Calibrated before/after each flight } \\
\text { with a spinning disk. }\end{array}$ \\
\hline Radiation & CCP-CIPgs: 15-960 $\mu \mathrm{m}$ & $\begin{array}{l}\text { Calibrated before/after each flight } \\
\text { with a spinning disk. }\end{array}$ \\
\hline & $\begin{array}{l}\text { SMART Albedometer, downward } \\
\text { spectral irradiance, } 300-2200 \mathrm{~nm}\end{array}$ & Weekly calibrations. \\
\hline
\end{tabular}

163

164

Table S3. List of compared measurement ranges and measurement variances caused by the spatial variation during the field campaign.

\begin{tabular}{|c|l|l|}
\hline $\begin{array}{c}\text { Measurement } \\
\text { Variables }\end{array}$ & \multicolumn{1}{|c|}{$\begin{array}{c}\text { Measured Range during the Field } \\
\text { Campaign }\end{array}$} & \multicolumn{1}{c|}{$\begin{array}{c}\text { Measurement Variances between the } \\
\text { Two Aircraft }\end{array}$} \\
\hline Static Pressure & $500-1010 \mathrm{hPa}$ & $<1 \%$ \\
\hline $\begin{array}{c}\text { Static air } \\
\text { temperature }\end{array}$ & $272-310 \mathrm{~K}$ & $<1 \%$ \\
\hline $\begin{array}{c}\text { Dewpoint } \\
\text { temperature }\end{array}$ & $230-300 \mathrm{~K}$ & $\begin{array}{l}\text { Without clouds, }<1 \% \\
\text { With clouds, the measurement from the G1 } \\
\text { can be up to 5\% lower than that of HALO }\end{array}$ \\
\hline $\begin{array}{c}\text { 3-D wind } \\
\text { conticle number } \\
\text { concentration }\end{array}$ & $1-15 \mathrm{~m} / \mathrm{s}$ & $<40 \%$ \\
\hline $\begin{array}{c}\text { Non-Refractory } \\
\text { particle chemical } \\
\text { composition }\end{array}$ & $<10 \mu \mathrm{g} \cdot \mathrm{m}^{-3}$ & $\begin{array}{l}<20 \% \text { for CPC, }<50 \% \text { for UHSAS (size } \\
\text { dependent) }\end{array}$ \\
\hline $\begin{array}{c}\text { CCN } \\
\text { concentration }\end{array}$ & $\mathrm{SS}=0.25 \%, 100-2000 \mathrm{~cm}^{-3}$ & $<10 \%$ above $2500 \mathrm{~m}$ \\
\hline $\begin{array}{c}\text { Gas phase } \\
\text { concentration }\end{array}$ & $\mathrm{Ozone:} 15-75 \mathrm{ppb}$ & Up to $50 \%$ below $2500 \mathrm{~m}$ \\
\hline $\begin{array}{c}\text { Cloud droplet } \\
\text { number } \\
\text { concentration }\end{array}$ & $3-20 \mu \mathrm{m}$ & $<10 \%$ above $2500 \mathrm{~m}$ \\
\hline $\begin{array}{c}\text { Downward } \\
\text { irradiance }\end{array}$ & $200-1500 \mathrm{~W} \cdot \mathrm{m}^{-2}$ & Up to $50 \%$ below $2500 \mathrm{~m}$ \\
\hline
\end{tabular}




\section{Reference}

170

171

172

173

174

175

176

177

178

179

180

181

182

183

184

185

186

187

188

189

190

191

192

193

194

195

196

197

198

199

200

201

202

203

204

205

206

207

208

209
Fan, J., Rosenfeld, D., Zhang, Y., Giangrande, S. E., Li, Z., Machado, L. A., Martin, S. T., Yang, Y., Wang, J., and Artaxo, P.: Substantial convection and precipitation enhancements by ultrafine aerosol particles, Science, 359, 411-418, 2018.

Kohler, H.: The nucleus in and the growth of hygroscopic droplets, Transactions of the Faraday Society, 32, 1152-1161, 1936.

Kotchenruther, R. A. and Hobbs, P. V.: Humidification factors of aerosols from biomass burning in Brazil, J Geophys Res-Atmos, 103, 32081-32089, 1998.

Moran-Zuloaga, D., Ditas, F., Walters, D., Saturno, J., Brito, J., Carbone, S., Chi, X. G., de Angelis, I. H., Baars, H., Godoi, R. H. M., Heese, B., Holanda, B. A., Lavric, J. V., Martin, S. T., Ming, J., Pohlker, M. L., Ruckteschler, N., Su, H., Wang, Y. Q., Wang, Q. Q., Wang, Z. B., Weber, B., Wolff, S., Artaxo, P., Poschl, U., Andreae, M. O., and Pohlker, C.: Long-term study on coarse mode aerosols in the Amazon rain forest with the frequent intrusion of Saharan dust plumes, Atmos Chem Phys, 18, 10055-10088, 2018.

Petters, M. D. and Kreidenweis, S. M.: A single parameter representation of hygroscopic growth and cloud condensation nucleus activity, Atmos Chem Phys, 7, 1961-1971, 2007.

Petters, M. D. and Kreidenweis, S. M.: A single parameter representation of hygroscopic growth and cloud condensation nucleus activity - Part 2: Including solubility, Atmos Chem Phys, 8, 6273-6279, 2008.

Petters, M. D. and Kreidenweis, S. M.: A single parameter representation of hygroscopic growth and cloud condensation nucleus activity - Part 3: Including surfactant partitioning, Atmos Chem Phys, 13, 1081-1091, 2013.

Pöschl, U., Martin, S., Sinha, B., Chen, Q., Gunthe, S., Huffman, J., Borrmann, S., Farmer, D., Garland, R., and Helas, G.: Rainforest aerosols as biogenic nuclei of clouds and precipitation in the Amazon, Science, 329, 1513-1516, 2010.

Schulz, C., Schneider, J., Amorim Holanda, B., Appel, O., Costa, A., de Sá, S. S., Dreiling, V., Fütterer, D., Jurkat-Witschas, T., Klimach, T., Krämer, M., Martin, S. T., Mertes, S., Pöhlker, M. L., Sauer, D., Voigt, C., Weinzierl, B., Ziereis, H., Zöger, M., Andreae, M. O., Artaxo, P., Machado, L. A. T., Pöschl, U., Wendisch, M., and Borrmann, S.: Aircraft-based observations of isoprene epoxydiol-derived secondary organic aerosol (IEPOX-SOA) in the tropical upper troposphere over the Amazon region, Atmos. Chem. Phys. Discuss., 2018, 1-32, 2018.

Shilling, J. E., Pekour, M. S., Fortner, E. C., Artaxo, P., Sá, S. d., Hubbe, J. M., Longo, K. M., Machado, L. A., Martin, S. T., and Springston, S. R.: Aircraft observations of the chemical composition and aging of aerosol in the Manaus urban plume during GoAmazon 2014/5, Atmos Chem Phys, 18, 10773-10797, 2018.

Wang, J., Krejci, R., Giangrande, S., Kuang, C., Barbosa, H. M., Brito, J., Carbone, S., Chi, X., Comstock, J., Ditas, F., Lavric, J., Manninen, H. E., Mei, F., Moran-Zuloaga, D., Pohlker, C., Pohlker, M. L., Saturno, J., Schmid, B., Souza, R. A., Springston, S. R., Tomlinson, J. M., Toto, T., Walter, D., Wimmer, D., Smith, J. N., Kulmala, M., Machado, L. A., Artaxo, P., Andreae, M. O., Petaja, T., and Martin, S. T.: Amazon boundary layer aerosol concentration sustained by vertical transport during rainfall, Nature, 539, 416-419, 2016. Williamson, C., Kupc, A., Wilson, J., Gesler, D. W., Reeves, J. M., Erdesz, F., McLaughlin, R., and Brock, C. A.: Fast time response measurements of particle size distributions in the 3-60 $\mathrm{nm}$ size range with the nucleation mode aerosol size spectrometer, Atmos Meas Tech, 11, 3491-3509, 2018. 